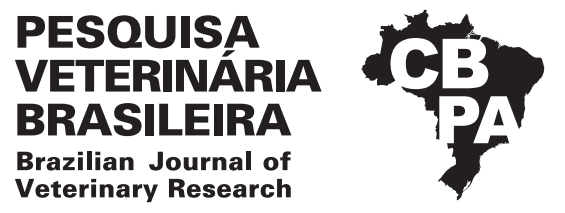

Pesq. Vet. Bras. 38(12):2254-2261, dezembro 2018 DOI: 10.1590/1678-5150-PVB-5528

Original Article

Animais Selvagens/WildLife Medicine

ISSN 0100-736X (Print)

ISSN 1678-5150 (Online)

\title{
Pathological and molecular findings of avian avulavirus type 1 outbreak in pigeons (Columba livia) of southern Brazil ${ }^{1}$
}

\author{
Suyene O. Souza ${ }^{2}$, Gabriela Fredo ${ }^{2}$, Priscilla M. Dupont ${ }^{2}$, Ronaldo V. Leite-Filho², \\ Jens P. Teifke ${ }^{3}$, Saulo P. Pavarini², Cláudio W. Canal² and David Driemeier ${ }^{2 *}$
}

\begin{abstract}
Souza S.O., Fredo G., Dupont P.M., Leite-Filho R.V., Teifke J.P., Pavarini S.P., Canal C.W. \& Driemeier D. 2018. Pathological and molecular findings of avian avulavírus type 1 outbreak in pigeons (Columba livia) of southern Brazil. Pesquisa Veterinária Brasileira 38(12):2254-2261. Universidade Federal do Rio Grande do Sul, Av. Bento Gonçalves 9090, Porto Alegre, RS 95320-000, Brasil. E-mail: davetpat@ufrgs.br

The Newcastle disease, caused by avian avulavirus type 1 strains (APMV-1) is an important avian disease involved into high rates of mortality and economic losses. Several outbreaks have been reported over the last 30 years in Columbiformes in different parts of the world, caused by a adapted variant strain of AAvV-1, called pigeon paramyxovirus type 1 (PPMV-1). A high mortality associated with an outbreak was analyzed in free-living pigeons (Columba livia) in a public square in Porto Alegre in Southern Brazil. A total of 24 pigeons moribund or freshly dead, within five weeks interval were submitted to necropsy, histopathological, immunohistochemical (anti-Newcastle), and RT-PCR followed by sequencing of the amplification products analysis. They presented neurological signs, non-suppurative encephalitis and encephalomyelitis, and mononuclear inflammatory infiltrate in different organs. Immunohistochemical analysis in nine pigeons tissue showed that anti-Newcastle was expressed in brain, kidney, liver and pancreas. The RT-PCR test for the M protein of Newcastle disease virus was positive in six pigeons. The differential diagnosis of Influenza, West Nile, Mycoplasma gallisepticum and Mycoplasma synoviae in all pigeons presented negative results. The sequence of amino acids in the cleavage site region of the F protein was ${ }^{112} \mathrm{RRQKRF}{ }^{117}$ classifying the strain as virulent. The phylogenetic analysis classified this virus strain into Class II and VI genotype.
\end{abstract}

INDEX TERMS: Molecular findings, avulavírus type 1, Columba livia, pigeons, PPMV-1, Newcastle disease, encephalomyelitis, columbiformes, immunohistochemistry, pathology.

RESUMO.- [Achados patológicos e moleculares da infecção por avulavirus aviário tipo $1 \mathrm{em}$ pombos (Columba livia) do sul do Brasil.] A doença de Newcastle, causada por cepas de avulavirus aviário tipo 1 (AAvV-1), é uma doença de aves importante por causar altos índices de mortalidade e perdas econômicas. Vários surtos têm sido relatados ao longo de 30 anos em aves da ordem Columbiformes, em diferentes partes do mundo, causados por uma cepa variante

\footnotetext{
${ }^{1}$ Received on April 14, 2018.

Accepted for publication on June 28, 2018.

${ }^{2}$ Universidade Federal do Rio Grande do Sul (UFRGS), Av. Bento Gonçalves 9090, Porto Alegre, RS 95320-000, Brazil. *Corresponding author: davetpat@ufrgs.br

${ }^{3}$ Bundesforschungsinstitut für Tiergesundheit Südufer, 10 D-1749, Greifswald, InselRiems.
}

específica de AAvV-1, denominada Pigeon paramyxovirus tipo 1 (PPMV-1). Foi analisado um surto de mortalidade em pombos domésticos (Columba livia), provenientes de uma praça pública em Porto Alegre, no Sul do Brasil. Vinte e quatro aves moribundas ou mortas foram submetidas, no intervalo de cinco semanas, ao exame de necropsia, exame histopatológico, imuno-histoquímico anti-Newcastle, RT-PCR e sequenciamento. Apresentaram sinais neurológicos, encefalite e encefalomielite não supurativas, além de infiltrado inflamatório mononuclear em diversos órgãos. Nove aves demonstraram exame imuno-histoquímico positivo em órgãos como cérebro, rim, fígado e pâncreas. Seis aves foram positivas no exame de RT-PCR para a proteína M do vírus da Doença de Newcastle. Nos exames de diagnósticos diferenciais de Influenza, West Nile, Mycoplasma gallisepticum e Mycoplasma synoviae, 
todas as aves testadas foram negativas. A sequência dos aminoácidos na região do sítio de clivagem da proteína foi ${ }^{112}{ }^{R R Q K R F}{ }^{117}$, classificando a cepa como virulenta. De acordo com a análise filogenética o vírus identificado foi classificado como pertencente à classe II e ao genótipo VI.

TERMOS DE INDEXAÇÃO: Avulavirus aviário tipo 1, Columba livia, pombos, PPMV-1, Doença de Newcastle, encefalomielite, Columbiformes, patologia.

\section{INTRODUCTION}

Avian avulavirus can be divided into nineteen species: AAvV-1 to AAvV-19 (ICTV 2015, 2017), and several avian species, including domestic and wild, can be affected (Alexander 2000a, Clavijo et al. 2000). Virulent strains of avian avulavirus type 1 (AAvV-1) causes Newcastle disease (ND), which is considered one of the most important avian diseases involved in high rates of mortality and economic losses, making the disease a notifiable condition to the World Organization for Animal Health (OIE 2012). In the past, Newcastle disease virus (NDV) was classified into at least three major pathotypes (lentogen, mesogen and velogen) based on the severity of the disease in chickens. Tests such as the mean time of death in eggs, the intravenous pathogenicity test and variations of these tests were used (Alexander \& Senne 2008), but, by international agreement, a definitive evaluation of virus virulence is based on the intracerebral test pathogenicity (ICPI). The current OIE definition also recognizes advances in understanding the molecular basis of pathogenicity and allows confirmation of virus virulence, but not the lack of virulence, by in vitro tests that determine the amino acid sequence at the cleavage site of the F0 protein (OIE 2012).

Several outbreaks in Columbiformes have been reported over the past 30 years in many parts of the world caused by an adapted variant $\mathrm{AAvV}-1$ denominated pigeon paramyxovirus 1 (PPMV-1) (Alexander 2011), which have been described in countries of the South America (Zanetti et al. 2001). These panzootic strains belong to genotype VI, which presents 9 subgenotypes (Dimitrov et al. 2016), and has been previously described in high mortality outbreaks worldwide in different species of birds (Alexander et al. 1985, 1997). Pigeons must be considered seriously as a potential source of NDV infection and disease for commercial poultry flocks (Kommers et al. 2002), and may be subclinically infected, spreading the virus for a considerable period of time without clinical signs (Carrasco et al. 2008, Catroxo et al. 2011). These may consist of apathy, anorexia, weight loss, prostration, diarrhea, polyuria, conjunctivitis, periocular edema, ruffled feathers, sneezing, dyspnea, incoordination, lack of balance, tremors, dehydration, proventricular dilatation, crop emptying problems, leukopenia and death. Some other symptomatic and asymptomatic birds had sudden death (Clavijo et al. 2000, Catroxo et al. 2012). Brazil has the status of free of pathogenic NDV in commercial poultry, and in the suspect of the disease the notification to the official veterinary service in the country is mandatory (Brasil 2007, Orsi et al. 2010).

In this paper, we describe the clinical signs, pathological and molecular findings of the first reported outbreak of an avian avulavirus type 1 infection in free-living pigeons (Columba livia) in Southern Brazil in the summer of 2014.

\section{MATERIALS AND METHODS}

Samples. The mortality losses of free-living pigeons (Columba livia) from a town square in the center of the city of Porto Alegre $\left(30^{\circ} 1^{\prime} 59^{\prime \prime} \mathrm{S}\right.$, $51^{\circ} 13^{\prime} 48^{\prime \prime}$ ) Rio Grande do Sul State, Brazil, were analyzed and evaluated. Necropsies were performed on 24 freshly dead pigeons that had exhibited neurological signs. Gross examinations were performed over five weeks (one pigeon in the first week, six pigeons in the following week, one pigeon in the third week, six pigeons in the fourth week, and ten pigeons in the fifth week). Tissue samples from all birds, but with the exception of spinal cord that was collected only from 17 birds, were collected for histological analyses, fixed in $10 \%$ neutral-buffered formalin, processed in a routine manner and stained with hematoxylin and eosin (HE) for histological examination. Dry cloacal and oropharyngeal swabs were collected, added with $1 \mathrm{~mL}$ of Phosphate Buffer Saline (PBS) pH 7.2 was added, mixed and stored at $-80^{\circ} \mathrm{C}$ until use. Tissue samples of $5.0 \mathrm{~g}$ (trachea, kidney, lung and brain) were grounded with $2.0 \mathrm{~g}$ autoclaved white sand in $5 \mathrm{~mL}$ of PBS ( $\mathrm{pH} 7.4$ ), centrifuged at 10,000 rpm for $10 \mathrm{~min}$ and $100 \mu \mathrm{L}$ of the supernatant was store at $-80^{\circ} \mathrm{C}$ for RNA extraction. Both tissue samples and swabs were analysed by PCR. For each bird, a full diagnostic assay was performed, such as histology, immunohistochemistry and PCR.

Immunohistochemistry. Immunohistochemistry (IHC) assay was performed in paraffin-embedded tissues of all birds, namely brain, liver, kidney and pancreas using the peroxidase method and using the primary antibody directly conjugated to a label. The tissues tested were chosen because they presented histological changes in most birds. The endogenous peroxidase activity was unmasked with hydrogen peroxide and methanol (1:9) for 20 minutes. To block the nonspecific sites the slides were incubated in 3\% fat-free dry milk (Molico, Nestle ' Brazil) for 30 minutes. For antigen retrieval, the sections were heated in $10 \mathrm{mM}$ citrate buffer $(\mathrm{pH} 6.0$ ) for $5 \mathrm{~min}$ at $100^{\circ} \mathrm{C}$ using a microwave oven. After antigen retrieval, the sections were incubated overnight in a humidified chamber at room temperature with a primary antibody (Rabbit anti-Newcastle, BIOSS $^{\circledR}$, bs-4814R-HRP/ Polyclonal antibody, HRP conjugated) used at 1:500 dilution in phosphate-buffered saline (PBS). The sections were revealed by 3-amino-9-ethylcarbazole (AEC, DakoCytomation ${ }^{\circledR}$, Inc. North America, Carpinteria, California, USA) counterstained with Mayer's hematoxylin for approximately $10 \mathrm{sec}$, coverslips were mounted using an aqueous mounting medium (S1964, DakoCytomation ${ }^{\circledR}$ ), and slides were examined using light microscopy. Positive (brain and liver tissues from a pigeon RT-PCR positive for NDV) and negative controls were incubated with antibody diluent (catalogue no. S3022, DakoCytomation ${ }^{\circledR}$ ).

RNA extraction and reverse transcription PCR (RT-PCR). RNA was extracted from $250 \mu \mathrm{L}$ of each sample using TRIzol ${ }^{\circledR} \mathrm{LS}$ Reagent (Life Technologies, Carlsbad, CA, USA) according to the manufacturer's instructions and eluted in $50 \mu \mathrm{L}$ of ultrapure water. The freeze-dried attenuated live vaccine Avinew ${ }^{\circledR}$ (Merial Animal Health Limited, Lyon, France) was used as a positive control and ultrapure water was used as a negative control. In order to detect NCDV, a previously described RT-PCR based on M protein gene amplified $231 \mathrm{bp}$ (Seal et al. 1995). The cDNA was synthesized with SuperScript ${ }^{\circledR}$ III Reverse Transcriptase Kit (Life Technologies) in a total volume of $20 \mu \mathrm{L}$, following the manufacturer's recommendations. The PCR was conducted in a total volume of $25 \mu \mathrm{L}$. The amplification products were separated by gel electrophoresis in $2.0 \%$ agarose using 0,1 $\mu \mathrm{g} / \mathrm{mL}$ of Blue Green Loading Dye I (LGC Biotecnologia, Cotia/SP, Brazil) in Tris-acetate buffer-EDTA (1x concentrated) (Sambrook et al. 1989). Visualization was done under UV light which 
was compared with amplification products with molecular weight standards scale of $100 \mathrm{bp}$ (Fermentas, USA).

Primer design for complete fusion protein (F) gene amplification. Twenty seven APMV-1 complete genome sequences were selected in GenBank ${ }^{\circledR}$ (http://www.ncbi.nlm.nih.gov/genbank/) in order to design primers for sequencing of complete $\mathrm{F}$ gene. The sequences were aligned using Molecular Evolutionary Genetics Analysis version 6 (MEGA6) (Tamura et al. 2013). The complete genome sequence of the strain AV 3224/96 (GenBank accession number GQ.429292.1) were selected for primer design due to the high identity with our samples and align using MEGA 6 with a complete fusion protein sequence of the isolate Amazon/Missouri/31378/1996 (GenBank acession number JN.942032.1). The primers were based on the fusion protein region of this sequence. Specific primers were selected to amplify the complete sequence of 1855 base pairs (bp) using Vector NTI Advance ${ }^{\circledR}$ Software (Life Technologies).

Amplification of the F protein gene by RT-PCR. The complete F protein gene was amplified using the 4 primers pairs (Table 1). The cDNA was synthesized with SuperScript ${ }^{\circledR}$ III ReverseTranscriptase Kit (Life Technologies) using Exo-Resistant Random Primer (Life Technologies), following the manufacturer's recommendations. Each primer pair was performed in a single PCR reaction and was conducted in a total volume of $25 \mu \mathrm{L}$ containing: $1 \times$ PCR buffer, $1 \mathrm{mM}$ of $\mathrm{MgCl}_{2}, 0.5 \mathrm{mM}$ of dNTP mix, $0.24 \mathrm{mM}$ of each forward and reverse primer and 1 unit of Platinum ${ }^{\circledR}$ Taq DNA Polymerase (Life Technologies), under the following conditions: an initial denaturation at $94^{\circ} \mathrm{C}$ for $3 \mathrm{~min}, 35$ cycles of $45 \mathrm{~s}$ for denaturation at $94^{\circ} \mathrm{C}, 45 \mathrm{~s}$ of primer annealing at $52^{\circ} \mathrm{C}, 45 \mathrm{~s}$ for extension at $72^{\circ} \mathrm{C}$ and a $7 \mathrm{~min}$ final extension at $72^{\circ} \mathrm{C}$. The amplification products were separated by gel electrophoresis in $2.0 \%$ agarose using $0,1 \mu \mathrm{g} / \mathrm{mL}$ of Blue Green Loading Dye I (LGC Biotecnologia, Cotia, SP, Brazil) in Trisacetate buffer-EDTA (1x concentrated) (Sambrook et al. 1989). Visualization was done under UV light which was compared with amplification products with molecular weight standards scale of 100bp (Fermentas, USA).

Sequencing and phylogenetic analysis. The PCR products generated by $\mathrm{M}$ and $\mathrm{F}$ protein were purified using the NucleoSpin Extract II Kit (Macherey-Nagel, Düren, Germany), and both DNA strands were sequenced with an ABI PRISM 3100 Genetic Analyzer (Applied Biosystems) using a BigDye Terminator v.3.1 cycle sequencing kit (Applied Biosystems). The gene sequences of the present study were assembled using SeqMan (DNASTAR Lasergene ${ }^{\circledR} 11$, Madison, USA). Nucleotide sequence editing, analysis, prediction of amino acid sequences and alignments were performed by using the software MEGA 6. For construction of $F$ protein phylogenetic tree, reference sequences representing reconized genotypes in class II and I were retrieved from Kim et al. (2008) and GenBank ${ }^{\circledR}$ (http://www.ncbi.nlm. nih.gov/genbank/) and aligned with BioEdit version 7.1.3 software

Table 1. Primers selected to sequence the F protein gene

\begin{tabular}{crc}
\hline Primer & Sequence (5'-3') & Target \\
\hline NC Fusion-1F & 5'CTATCTAATTAGAAAAAACACGGGTAGAAG3' & F \\
NC Fusion-1R & 5'TGAGTTAGGGCAGGGGAAGT3' & F \\
NC Fusion-2F & 5'GCAACAGTTTGTCAATGACCAA3' & F \\
NC Fusion-2R & 5'TGTATTGCCGCTCAGACAAGA3' & F \\
NC Fusion-3F & 5'AGGTAGTGACACAAGTCGGCTCTG3' & F \\
NC Fusion-3R & 5'AACGATATAGGTAATGAGAGCAGATGT3' & F \\
NC Fusion-4F & 5'ATCGTGACAGGCAACCTTGATATATC3' & F \\
NC Fusion-4R & 5'CCGTTCTACCCGTGTATTGCT3' & F
\end{tabular}

using CLUSTAL W. Molecular Evolutionary Genetics Analysis version 6 (MEGA6) (Tamura et al. 2013) was used for phylogeny inference according to the Maximum Likelihood criterion and the General Time Reversible model. The robustness of the hypothesis was tested with 1000 non-parametric bootstrap analyses.

Additional exams. Out of 24 pigeons examined for NDV, six were also tested, using PCR, for Influenza virus, West Nile virus, Mycoplasma gallisepticum, and Mycoplasma synoviae. PCR tests for Mycoplasma gallisepticum and Mycoplasma synoviae were performed with NewGene MGAmp and NewGene MSAmp, respectively.

\section{RESULTS}

\section{Clinical and epidemiological features}

A mortality surge in free-living pigeons (Columba livia) from a public square in the city of Porto Alegre in Southern Brazil in November of 2014 was analyzed. The death of these birds was notified to the official Brazilian veterinary service. Clinical signs observed included tremors of the head, stiff neck, lack of balance, incoordination, paresis, paralysis, drooped wings, and regurgitation (Fig.1A). The approximate number of dead pigeons observed was 120 . However, the exact number of birds involved was not obtainable as the birds are free-living and the authors only had access to a limited portion of their habitat. The data provide epidemiological information including the time between the onset of clinical signs and death (an average of 24-48h). There were no reports that other bird species had died in this square. Only adult free-living pigeons were affected, all of them have a regular body condition and both males and females were analyzed. The birds had access to a fountain and fed on what they found on the ground.

\section{Gross findings}

Gross findings included multifocal to coalescing subdural hemorrhages in all segments in the spinal cord (8/24) (Fig.1B). The proventriculus and small intestine serous showed marked hyperemia. Both the spleen and liver were markedly enlarged, and hyperemic. The pancreas showed a mildly increase in size and a multifocal whitish color. In a focally extensive area of the dorsal cervical region, bright areas of hemorrhage extended into the subcutis. No other significant gross abnormalities were noted.

\section{Microscopic findings}

The histopathological alterations in organs were as follows, kidney (22/24), liver (20/24), pancreas (19/24), brain $(18 / 24)$, spleen $(13 / 24)$, spinal cord $(8 / 17)$, testis $(5 / 11)$, and oviduct (2/13) (Table 2). A histopathologic examination revealed non-suppurative encephalitis and encephalomyelitis involving all compartments of the central nervous system, with prominent perivascular lymphoplasmacytic cuffing (14/24), microgliosis (12/24) (Fig.2A), neuronophagia $(8 / 24)$, neuropil vacuolization $(4 / 24)$, lymphoplasmacytic meningitis (4/24) and Gitter cells (3/24). In the spinal cord perivascular lymphoplasmacytic cuffing (7/17), microgliosis (5/17)(Fig.2B), neuronophagia (3/17), vascular proliferation (3/17), hyperemia in the dura mater (3/17), Gitter cells (2/17), lymphoplasmacytic meningitis $(1 / 17)$, gliosis $(1 / 17)$, and neuropil vacuolization (1/17) were observed. One pigeon had eosinophilic intracytoplasmic inclusions measuring 3-5 $\mu \mathrm{m}$ in neurons in the gray matter of the spinal cord. In the kidneys, multifocal lymphoplasmacytic and rare macrophages were 


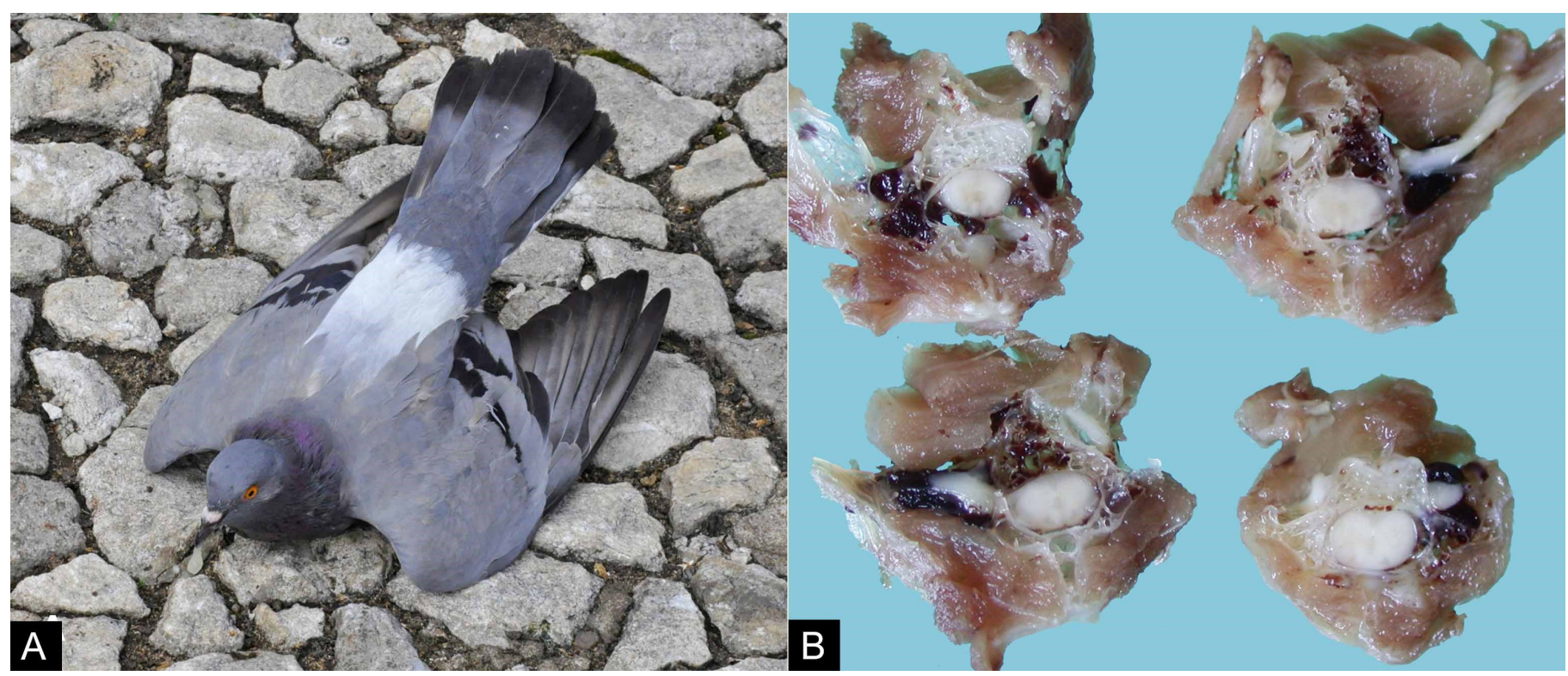

Fig.1. Clinical-pathological characterization of Paramyxovirus infection in Columbiformes. (A) Pigeon. Note the impaired locomotion causing it to stand on its wings. (B) Pigeon, spinal cord. Cross section, areas of subdural hemorrhage.

Table 2. List of animal outbreaks and the period in which they were assessed, affected organs and the results of RT-PCR and immunohistochemistry analyses

\begin{tabular}{|c|c|c|c|c|}
\hline Bird no. & $\begin{array}{l}\text { Week of } \\
\text { receipt }\end{array}$ & $\begin{array}{c}\text { Affected } \\
\text { organs }\end{array}$ & $\begin{array}{c}\text { RT-PCR M } \\
\text { protein }\end{array}$ & Immunohistochemistry \\
\hline 1 & $1^{\underline{a}}$ & B, Li, P, K, S & ND & $+\mathrm{B}$ \\
\hline 2 & $2^{\underline{a}}$ & $\mathrm{~B}, \mathrm{P}, \mathrm{K}, \mathrm{S}$ & + & $+\mathrm{P}+\mathrm{B}+\mathrm{K}$ \\
\hline 3 & $2^{\mathrm{a}}$ & $\mathrm{P}, \mathrm{K}$ & - & - \\
\hline 4 & $2^{\underline{a}}$ & $\mathrm{P}, \mathrm{K}, \mathrm{S}$ & + & - \\
\hline 5 & $2^{\underline{a}}$ & B & - & $+\mathrm{B}$ \\
\hline 6 & $2^{\underline{a}}$ & B, Li, S, P, K & - & - \\
\hline 7 & $2^{\mathrm{a}}$ & B & + & $+\mathrm{B}$ \\
\hline 8 & $3^{\underline{a}}$ & $\begin{array}{c}\text { B, SC, S, Li, } \\
\text { K, T }\end{array}$ & - & - \\
\hline 9 & $4^{\underline{a}}$ & $\begin{array}{c}\text { B, SC, Li, S, } \\
\text { K, P }\end{array}$ & - & $+\mathrm{B}$ \\
\hline 10 & $4 \underline{a}$ & $\begin{array}{c}\mathrm{SC}, \mathrm{S}, \mathrm{K}, \mathrm{Li}, \\
\mathrm{P}, \mathrm{T}\end{array}$ & + & $+\mathrm{Li}$ \\
\hline 11 & $4^{\mathrm{a}}$ & B, P, K, Li, B & - & - \\
\hline 12 & $4 \underline{a}$ & B, P, K, Li, B & - & - \\
\hline 13 & $4 \underline{a}$ & B, P, K, Li, B & + & $+\mathrm{Li}$ \\
\hline 14 & $4 \stackrel{\mathrm{a}}{ }$ & $\begin{array}{c}\text { B, SC, P, K, } \\
\text { Li, S }\end{array}$ & + & $+\mathrm{Li}+\mathrm{B}$ \\
\hline 15 & $5^{\underline{a}}$ & $\begin{array}{c}\text { B, SC, P, K, } \\
\text { Li, S }\end{array}$ & - & - \\
\hline 16 & $5^{\mathrm{a}}$ & $\begin{array}{c}\text { B, Li, SC, P, } \\
\text { K, O }\end{array}$ & - & $+\mathrm{Li}$ \\
\hline 17 & $5 \underline{a}$ & S, P, Li, K & - & - \\
\hline 18 & $5^{\underline{a}}$ & B, P, K, Li, S, T & - & - \\
\hline 19 & $5^{\underline{a}}$ & B, Li, K & - & - \\
\hline 20 & $5^{\underline{a}}$ & $\mathrm{~K}, \mathrm{Li}, \mathrm{P}, \mathrm{T}$ & - & - \\
\hline 21 & $5^{\underline{a}}$ & $\begin{array}{c}\text { B, SC, P, K, } \\
\text { Li, S }\end{array}$ & - & - \\
\hline 22 & $5^{\mathrm{a}}$ & B, P, K. Li, S & - & - \\
\hline 23 & $5^{\mathrm{a}}$ & B, SC, Li, K, T & - & - \\
\hline 24 & $5^{\mathrm{a}}$ & $\mathrm{P}, \mathrm{K}, \mathrm{Li}$ & - & - \\
\hline
\end{tabular}

observed in the interstitial nephritis (22/24) (Fig.2C), as well as necrosis of tubular epithelial cells (3/24) and hemorrhage $(2 / 24)$. In the spleen, hemosiderosis $(14 / 24)$, lymphoid necrosis associated with fibrin deposition (10/24), lymphoid depletion (6/24), macrophage infiltration, and hemorrhage $(2 / 24)$ were observed. In the liver, periportal lymphocytes, plasma cells, macrophage, and heterophil infiltration (20/24) were observed (Fig.2D). In the pancreas, lymphocytic infiltrate $(17 / 24)$ was found and was occasionally associated with extensive necrosis (6/24) (Fig.2E). Lymphocytic infiltration was observed in two female oviducts, and five males had testicles with tubular degeneration that was occasionally associated with lymphocytic infiltration.

\section{Immunohistochemistry}

ND virus antigens were detected multifocally and were characterized by a granular immunostaining in the cytoplasm of neurons (6/24) (Fig.2F), macrophages in the liver (4/24), epithelial cells in the exocrine pancreas (1/24), and in epithelial cells in the kidney $(1 / 24)$ (Table 2$)$.

\section{RT-PCR and phylogenetic analysis}

Six out of the 23 pigeons analyzed were positive for NDV by RT-PCR for the matrix (M) protein gene (Table 2). The complete gene and the coding sequence of the fusion (F) gene, according to the unified NDV classification system, indicated that the strain had a cleavage site, ${ }^{112} \mathrm{RRQKRF}^{117}$, which was characteristic of velogenic strains. Phylogenetic analysis of protein $\mathrm{F}$ showed that this strain could be classified into class II and genotype VI (Fig.3).

\section{Additional exams}

A total of six pigeons tested negative for Influenza virus A, West Nile virus, Mycoplasma gallisepticum, and Mycoplasma synoviae by PCR assay. 


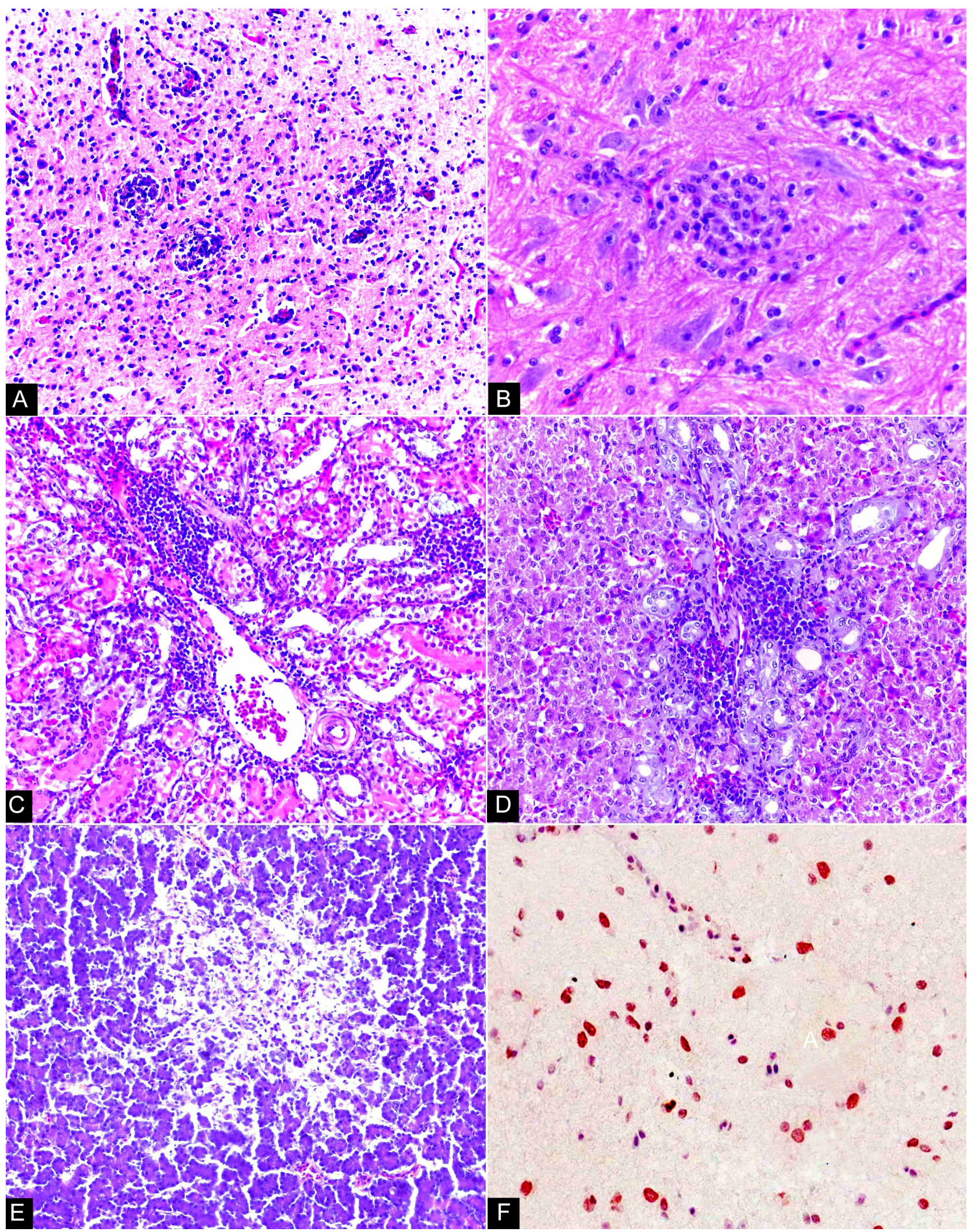

Fig.2. Histopathologic and immunohistochemical characterization of Paramyxovirus infection in Columbiformes. (A) Brain. Perivascular lymphoplasmacytic cuffing and mild microgliosis. HE, obj.20x. (B) Spinal cord. Mild nodular microgliosis. HE, obj.40x. (C) Kidney. Lymphoplasmacytic multifocal interstitial infiltrate associated with rares macrophages and necrosis of tubular epithelial cells. HE, obj.40x. (D) Liver. Focal area of mild periportal inflammatory infiltrate constituted by lymphocytes, plasma cells, macrophages, and heterophils, in addition to mild bile duct proliferation. HE, obj.40x. (E) Pancreas. Focal area of necrosis of pancreatic acini. HE, obj.40x. (F) Brain. Positive immunostaining in the cytoplasm of neurons for Newcastle Disease virus. AEC, obj.40x. 

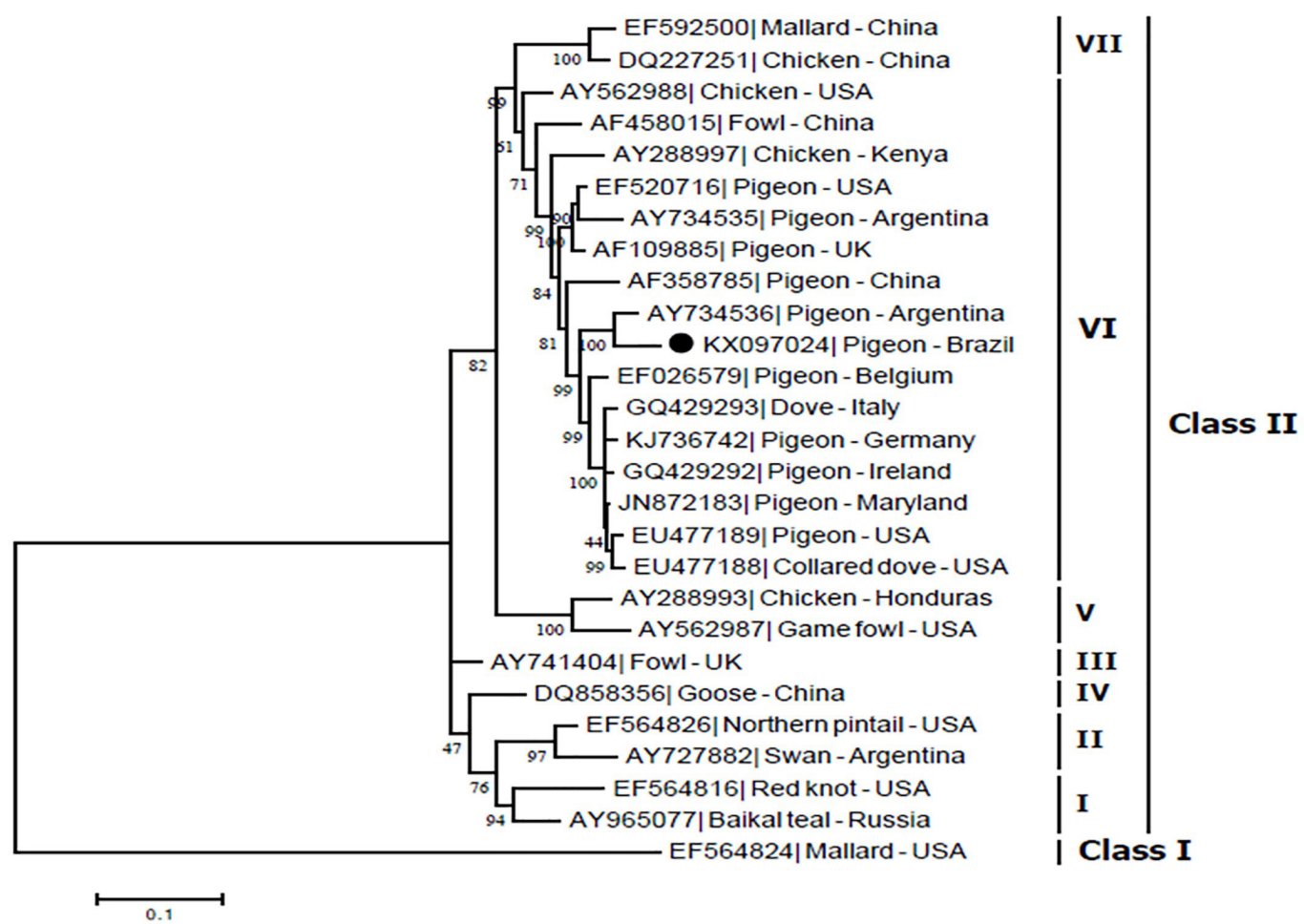

Fig.3. Molecular phylogenetic analysis of paramyxovirus type I F protein by Maximum Likelihood method. Phylogenetic analysis showed that this strain could be classified into class II and genotype VI clade, which includes the strain described in the present study and the reference strain AY734536.1/Pigeon-Argentina.

\section{DISCUSSION}

The diagnosis of paramyxovirus infection was confirmed through histological, immunohistochemical, and molecular analyses. The pigeons in this study presented neurological signs that included ataxia, imbalance, head tremors, incoordination, torticollis, and inability to fly, which are the same as those described as the primary signs of this disease observed in the order Columbiformes (Barton et al. 1992). The gross findings were nonspecific. However, most of the pigeons presented a focally extensive area of hemorrhage in the dorsal cervical region that extended into the subcutis. Columbiformes are known to exhibit a prominent vascular plexus in the cervical region (Werther 2007), which may have been injured in these birds due to the tremors and head rotation they displayed.

The histological lesions observed in the central nervous system and organs of the coelomic cavity of these pigeons were similar to those described in the literature (Bhaiyat et al. 1994, Brown et al. 1999, Kuiken et al. 1999, Ecco et al. 2011). The large amount of AAvV-1 found in the brains of experimentally infected pigeons suggests a high concentration of this viral strain in the central nervous system (Kommers et al. 2002), justifying the presence of lesions in the CNS found in the majority of pigeons analyzed in our study.

Immunohistochemical positive staining was found in nine pigeons of 24 tested. The absence of staining in the tissue samples from the other pigeons could be related to the period of infection; in some cases, there was no association between injury and the presence of the virus. The absence of positive staining may also indicate that undetectable amounts of virus can generate inflammatory lesions (Ecco et al. 2011) due to the greater sensitivity of nervous tissue (Brown et al. 1999). Viral replication may not be the only mechanism of neuronal damage; some damage likely occurs due to vascular impairment, and direct neuronal necrosis may be caused by the virus (Ecco et al. 2011). One bird exhibited the deposition of eosinophilic granular material in neuron bodies in an experimental infection study (Kommers et al. 2002), and another showed the same structures in respiratory epithelial cells and neuroglia cells (Hamid et al. 1991). In our study, immunohistochemical analysis did not reveal positive staining in these spinal cord structures. Therefore, it is not possible to state that these are paramyxovirus particles.

The pigeons examined in the last week of the outbreak were not RT-PCR positive, possibly because they were close to the end of the clinical course of the disease. It was not possible to identify viral material in the cloaca and trachea swabs or in the organs. Experimental infection studies with AAvV-1 strains have shown that pigeons primarily eliminate the virus in the first few days after infection (Dortmans et al. 2011). In tissues, positive PCR results were observed more frequently until the sixth day after infection (Hamid et al. 1991). RT-PCR analysis and sequencing were effective for the virus detection and in the deduction of virulence (Alexander et al. 2012). These techniques have been widely used because they are faster and less laborious than in vivo tests (Alexander 2000b), allowing for phylogenetic studies to determine the source and possible spread and mutation of a given strain. These techniques are also a good alternative in outbreaks (Aldous \& Alexander 2001). In this study, they were effective and 
essential diagnostic tools. In the present study, it was possible to observe that infections with a longer period of evolution can exhibited histological lesions without the presence of the virus, considering that the cases observed in the last week of the outbreak were negative in the immunohistochemical assay and the PCR.

Currently, ND is defined as a poultry infection caused by $\mathrm{AAvV}-1$ that either has an ICPI greater than 0.7 or has multiple basic amino acids in the $\mathrm{C}$-terminus of the $\mathrm{F} 2$ protein and the $\mathrm{N}$-terminus of the F1 protein (OIE 2012). Sequencing enables the detection of a strain that may be highly pathogenic for chickens and may cause a Newcastle disease outbreak upon crossing biosafety barriers and infecting poultry.

Differential diagnoses include Influenza virus A, West Nile virus, Mycoplasma gallisepticum, and Mycoplasma synoviae, agents that can cause damage to the central nervous system (Swayne et al. 2001, Swayne 2008). None of the pigeons tested was positive for these agents. Therefore, it is extremely important to use histology in conjunction with other diagnostic tools. Whereas immunohistochemical analysis enables the differentiation of ND from other agents, RT-PCR analysis and sequencing directly determines virulence.

The potential of the carrier pigeon to introduce ND in certain areas has been reported (Alexander 2000b), including in South American countries (Zanetti et al. 2001, Castro et al. 2012). The strain identified in the present study demonstrated homology with the strain that was identified in an Argentinian outbreak (Zanetti et al. 2001), relatively close to the state of Rio Grande do Sul. The mortality outbreak in this study occurred near the Guaiba River (in the eastern portion of the Rio Grande do Sul State, at the intersection of $50^{\circ}$ and $52^{\circ}$ west longitude and $30^{\circ}$ and $31^{\circ}$ south latitude). The hypothesis that the infection was acquired from aquatic and wild birds inhabiting this region (Accordi \& Barcellos 2006) cannot be ruled out.

NDV is a pathogen with zoonotic potential, and the most common sign of infection in humans is conjunctivitis that develops within 24 hours of NDV exposure to the eye (Swayne \& King 2003). Isolation of a pigeon-like APMV-1 from the lung tissue, urine, and feces of an immunocompromised patient who died of pneumonia has been reported (Goebel et al. 2007). Urban pigeons (Columba livia) may serve as reservoirs, carriers, and transmitters of various pathogens, and pose a risk to public health (Werther 2007). The free-living pigeons (Columba livia) in the present study were transient and living in the town square in the center of the city where they were fed, thus, they may be in frequent contact with humans.

After natural transmission from pigeons to chickens, PPMV-1 strains may become more virulent and lead to major outbreaks (Meulemans et al. 2002). The specific strain of PPMV-1 carried by pigeons can cause severe lesions in infected chickens (Kommers et al. 2002). Commercial poultry may be susceptible to the identified strain responsible for the outbreak presented in this study. The identified strain is pathogenic for pigeons because the clinical signs that are presented in this study are similar to those reported in the literature (Brown et al. 1999). The lesions that were found were mostly present in the central nervous system and were associated with the identification of the agent through immunohistochemical examination, which strongly suggests that the strain involved in this study is neurotropic. These results indicate the presence of an AAvV-1 with the potential to cause Newcastle disease if it is transmitted to poultry. Biosafety measures and virus surveillance must be increased to prevent this disease from causing further infections in this region.

Acknowledgments.- The authors thank CNPq (Brazilian National Council of Research) for the indispensable funding and support for this research.

Conflict of interest statement.- The authors do not have any potential conflicts of interest to declare.

\section{REFERENCES}

Accordi I.A. \& Barcellos A. 2006. Composição da avifauna em oito áreas úmidas da Bacia Hidrográfica do Lago Guaíba, Rio Grande do Sul. Revta Bras. Ornitol. 14(2):101-115.

Aldous E.W. \& Alexander D.J. 2001. Detection and differentiation of Newcastle disease virus (avian paramyxovirus type 1). Avian Pathol. 30(2):117-128. <http://dx.doi.org/10.1080/03079450120044515> <PMid:19184885>

Alexander D.J. 2000a. Newcastle disease in ostriches (Struthio camelus): a review. Vet. Pathol. 29(2):95-100. <PMid:19184794>

Alexander D.J. 2000b. Newcastle disease and other avian paramyxoviruses. Revta Sci. Tech., Off. Int. Epiz. 19(2):443-462. <PMid:10935273>

Alexander D.J. 2011. Newcastle disease in the European Union 2000 to 2009. Avian Pathol. 40(6):547-558. <http://dx.doi.org/10.1080/03079457.20 11.618823> <PMid:22107088>

Alexander D.J. \& Senne D.A. 2008. Newcastle disease, other avian paramyxoviruses, and pneumovirus infections, p.75-115. In: Saif Y.M., Fadly A.M., Glisson J.R., McDougald L.R., Nolan L.K. \& Swayne D.E. (Eds), Disease of Poultry. 12th ed. Blackwell, Ames.

Alexander D.J., Aldous E.W. \& Fuller C.M. 2012. The long view: a selective review of 40 years of Newcastle disease research. Vet. Pathol. 41(4):329335. <PMid:22834545>

Alexander D.J., Manvell R.J., Frost K.M., Pollitt W.J., Welchman D. \& Perry K. 1997. An outbreak of Newcastle disease in pheasants in Great Britain in May 1996. Vet. Rec. 140(1):20-22. <http://dx.doi.org/10.1136/vr.140.1.20> <PMid:9004478>

Alexander D.J., Russell P.H., Parsons G., Elzein E.M.E.A., Ballouh A., Cernik K., Engstrom B., Fevereiro M., Fleury H.J.A., Guittet M., Kaleta E.F., Kihm U., Kosters J., Lomniczi B., Meister J., Meulemans G., Nerome K., Petek M., Pokomunski S., Polten B., Prip M., Richter R., Saghy E., Samberg Y., Spanoghe L. \& Tumova B. 1985. Antigenic and biological characterisation of avian paramyxovirus type I isolates from pigeons an international collaborative study. Avian Pathol. 14(3):365-376. <http://dx.doi.org/10.1080/03079458508436238> <PMid:18766929>

Barton J.T., Bickford A.A., Cooper G.L., Charlton B.R. \& Cardona C.J. 1992. Avian paramyxovirus type 1 infections in racing pigeons in California. I. Clinical signs, pathology, and serology. Avian Dis. 36(2):463-468. <http:// dx.doi.org/10.2307/1591531> <PMid:1385700>

Bhaiyat M.I., Ochiai K., Itakura C., Islam M.A. \& Kida H. 1994. Brain lesions in young broiler chickens naturally infected with a mesogenic strain of Newcastle disease virus. Avian Pathol. 23(4):693-708. <http://dx.doi. org/10.1080/03079459408419038> <PMid:18671135>

Brasil 2007. Ministério da Agricultura Pecuária e Abastecimento. Plano de contingência para Influenza aviária e doença de Newcastle. Available at <http://www.idaron.ro.gov.br/Multimidia/ctGidsa/arquivos/Plano. de.Contingencia.pdf> Accessed on Apr. 13, 2018.

Brown C., King D.J. \& Seal B.S. 1999. Pathogenesis of Newcastle disease in chickens experimentally infected with viruses of different virulence. Vet. Pathol. 36(2):125-132. <http://dx.doi.org/10.1354/vp.36-2-125> <PMid:10098640> 
Carrasco A.O.T., Sekin M.C., Raso T.F., Paulillo A.C. \& Pinto A.A. 2008. Experimental infection of Newcastle disease virus in pigeons (Columba livia): Humoral antibody response, contact transmission and viral genome shedding. Vet. Microbiol. 129(1/2):89-96. <http://dx.doi.org/10.1016/j. vetmic.2007.11.012><PMid:18166283>

Castro E.R., Zanetti F. \& Arbiza J. 2012. Genetic characterization of a pigeon paramyxovirus Type 1 isolated from Columba livia in Uruguay. Avian Dis. 56(1):243-248. <http://dx.doi.org/10.1637/9835-061611-Case.1> <PMid:22545555>

Catroxo M.H.B., Martins A.M.C.R.P.F., Petrella S., Curi N.A. \& Melo N.A. 2011. Research of viral agent in free-living pigeon feces (Columba livia) in the city of São Paulo, SP, Brazil, for transmission electron microscopy. Int. J. Morphol. 29(2):628-635. <http://dx.doi.org/10.4067/S0717-95022011000200055>

Catroxo M.H.B., Martins A.M.C.P.F., Petrella S., Milanelo L., Aschar M., Souza F., Nastari B.D.B. \& Souza R.B. 2012. Avian paramyxoviruses, detection by transmission electron microscopy techniques. Int. J. Morphol.30(2):723730. <http://dx.doi.org/10.4067/S0717-95022012000200062>

Clavijo A., Robinson Y., Booth T. \& Munroe F. 2000. Velogenic Newcastle disease in imported caged birds. Can. Vet. J. 41(5):404-406. <PMid:10816836>

Dimitrov K.M., Ramey A.M., Qiu X., Bahl J. \& Afonso C.L. 2016. Temporal, geographic, and host distribution of avian paramyxovirus 1 (Newcastle disease vírus). Infect. Genet. Evol. 39:22-34.<http://dx.doi.org/10.1016/j. meegid.2016.01.008><PMid:26792710>

Dortmans J.C.F.M., Koch G., Rottier P.J.M. \& Peeters B.P.H.A. 2011. A comparative infection study of pigeon and avian paramyxovirus type 1 viruses in pigeons: evaluation of clinical signs, virus shedding and seroconversion. Avian Pathol. 40(2):125-130. <http://dx.doi.org/10.1080/03079457.20 10.542131><PMid:21500031>

Ecco R., Susta L., Afonso C.L., Miller P.J. \& Brown C. 2011. Neurological lesions in chickens experimentally infected with virulent Newcastle disease virus isolates. Avian Pathol. 40(2):145-152.<http://dx.doi.org/10.1080/0307 9457.2010.544289><PMid:21500034>

Goebel S.J., Taylor J., Barr B.C., Kiehn T.E., Castro-Malaspina H.R., Hedvat C.V., Rush-Wilson K.A., Kelly C.D., Davis S.W., Samsonoff W.A., Hurst K.R., Behr M.J. \& Masters P.S. 2007. Isolation of avian paramyxovirus 1 from a patient with a lethal case of pneumonia. J. Virol. 81(22):12709-12714. <http:// dx.doi.org/10.1128/JVI.01406-07><PMid:17855523>

Hamid H., Campbell R.S.F. \& Parede L. 1991. Studies of the pathology of velogenic Newcastle disease: virus infection in nonimmune and immune birds. Avian Pathol. 20(4):561-575. <http://dx.doi.org/10.1080/03079459108418796> <PMid:18680054>

ICTV 2015. International Committee on Taxonomy of Viruses. Available at $<\mathrm{http} / / /$ www.ictvonline.org/taxonomyHistory.asp?taxnode_id=20140755\&taxa_ name $=$ Newcastle\%20disease\%20virus > Accessed on Mar. 10, 2015.

ICTV 2017. International Committee on Taxonomy of Viruses. Available at $<\mathrm{http} / / /$ www.ictvonline.org/taxonomyHistory.asp?taxnode_id=20140755\&taxa_ name $=$ Newcastle\%20disease\%20virus $>$ Accessed on Apr. 13, 2018.

Kim L.M., King D.J., Guzman H., Tesh R.B., Rosa A.P.T., Bueno Junior R., Dennett J.A. \& Afonso C.L.. 2008. Biological and phylogenetic characterization of pigeon Paramyxovirus Serotype 1 Circulating in wild north american pigeons and doves. J. Clin. Microbiol. 46(10):3303-3310. <http://dx.doi. org/10.1128/JCM.00644-08> <PMid:18716227>
Kommers G.D., King D.J., Seal B.S., Carmichael K.P. \& Brown C.C. 2002. Pathogenesis of six pigeon-origin isolates of Newcastle Disease Virus for domestic chickens. Vet. Pathol. 39(3):353-362. <http://dx.doi.org/10.1354/ vp.39-3-353> <PMid:12014499>

Kuiken T., Wobeser G., Leighton F.A., Haines D.M., Chelack B., Bogdan J., Hassard L., Heckert R.A. \& Riva J. 1999. Pathology of Newcastle disease in double-crested cormorants from Saskatchewan, with comparison of diagnostic methods. J. Zoo Wildl. Med. 35(1):8-23. <PMid:10073341>

Meulemans G., Van den Berg T.P., Decaesstecker M. \& Boschmans M. 2002. Evolution of pigeon Newcastle disease virus strains. Avian. Pathol. 31(5):515-519. <http://dx.doi.org/10.1080/0307945021000005897> $<$ PMid:12427346>

OIE 2012. Newcastle disease (infection with Newcastle disease). World Organisation for Animal Health Terrestrial Manual, World Organisation for Animal Health. Chapter 2.3.14. Available at <http://www.oie.int/ fileadmin/Home/eng/Health_standards/tahm/2.03.14_NEWCASTLE_DIS. pdf> Accessed on May 1, 2016.

Orsi M.A., Doretto Junior L., Camillo S.C.A., Reischak D., Ribeiro S.A.M., Ramazzoti A., Mendonça A.O., Spilki F.R., Buzinaro M.G., Ferreira H.L. \& Arns C.W.. 2010. A survey for maintenance of virulent newcastle disease virus-free area in poultry production in Brazil. Braz. J. Microbiol. 41(2):368-375. <http:// dx.doi.org/10.1590/S1517-83822010000200017> <PMid:24031506>

Sambrook J., Fritschi E.F. \& Maniatis T. 1989. Molecular Cloning: a laboratory manual. 2nd ed. Cold Spring Harbor Laboratory Press, New York. 1659p.

Seal B.S., King D.J. \& Bennett J.D. 1995. Characterization of Newcastle Disease virus isolates by Reverse Transcription PCR coupled to direct nucleotide sequencing and development of sequence database for pathotype prediction and molecular epidemiological analysis. J. Clin. Microbiol. 33(10):26242630. <PMid:8567895>

Swayne D.E. 2008. Nervous system, p.260-291. In: Fletcher O.J. (Ed), Avian Histopathology. 3rd ed. Omni Press, Madison.

Swayne D.E. \& King D.J. 2003. Avian influenza and Newcastle disease. J. Am. Vet. Med. Assoc. 222(11):1534-1540. <http://dx.doi.org/10.2460/ javma.2003.222.1534><PMid:12784958>

Swayne D.E., Beck J.R., Smith C.S., Shieh W. \& Zaki S.R. 2001. Fatal encephalitis and myocarditis in young domestic geese (Anser anser domesticus) caused by West Nile Virus. Emerg. Infect. Dis. 7(4):751-753. <http://dx.doi. org/10.3201/eid0704.017429><PMid:11585545>

Tamura K., Stecher G., Peterson D., Filipski A. \& Kumar S. 2013. MEGA6: molecular evolutionary genetics analysis version 6.0. Mol. Biol.Evol. 30(12):27252729. <http://dx.doi.org/10.1093/molbev/mst197><PMid:24132122>

Werther K. 2007. Columbiformes (Pomba, Rolinha, Avoante, Juriti), p.268289. In: Cubas Z.S., Silva J.C.R. \& Catão-Dias J.L. (Eds), Tratado de Animais Selvagens. Vol.1. Roca, São Paulo.

Zanetti F., Mattiello R., Garbino C., Kaloghlian A., Terrera M.V., Boviez J., Palma E., Carrillo E. \& Berinstein A. 2001. Biological and molecular characterization of a pigeon Paramyxovirus Type-1 isolate found in Argentina. Avian Dis. 45(3):567-571. <http://dx.doi.org/10.2307/1592896><PMid:11569728> 